\title{
A Study on Sugarcane Production in India
}

\author{
T.S. Krishnamoorthy Durgesh Nandhini \\ Lady Doak College, Madurai, India \\ Venkittanaranappa Padmavathy \\ The American College, Madurai, India
}

\begin{abstract}
India is the largest producer and consumer of sugar in the World. About 45 million sugarcane farmers, their dependents and a large agricultural force, constituting 7.5 percent of the rural population, are involved in sugarcane cultivation, harvesting and ancillary activities. This enabled India to become the largest producer of sugarcane and sugar in the world leaving the other major producers Brazil and Cuba. ${ }^{l}$ The major sugarcane crop growing states in India are Uttar Pradesh, Bihar, Assam, Haryana, Gujarat, Maharashtra, Karnataka and Tamil Nadu. The sugarcane cultivation and sugar industry in India plays a vital role towards socio-economic development in the rural areas by mobilizing rural resources and generating higher income and employment opportunities. The major problem of sugarcane in India is based on monsoon and water supply. The cyclical nature in sugar production has caused distortions in the export of sugar in India. This study analyzes the state-wise production and reasons for the changes in production of sugarcane in the time period of 2000-2010.
\end{abstract}

\section{INTRODUCTION}

India has been known as the original home of sugarcane and sugar. India is the second largest producer of sugar in the World after Brazil and produces more of cane sugar and not beet sugar. Sugarcane is the important commercial crop of the country. In India, sugarcane is the key raw material, planted once a year during January to March. It is the major cost driver for the production of sugar. The following chart 1 indicates the region and states producing sugarcane.

Chart 1 indicating the region and the states involved in sugarcane production in India

\begin{tabular}{|ll|}
\hline REGION & STATES \\
\hline Subtropical & Uttar Pradesh, Bihar, Haryana \\
\hline Tropical & Maharashtra, Gujarat, Tamil Nadu, Andhra Pradesh, Karnataka \\
\hline
\end{tabular}

The production of sugar is spread across the country. In the above states, they are classified into three groups according to its production capacity. They are, the high sugar producing states are Maharashtra and Uttar Pradesh. The second category was the medium sugar producing states. They are Gujarat, Andhra Pradesh, Tamil Nadu, Karnataka, and Haryana. The remaining States are low producing States. They were Bihar and Assam. ${ }^{2}$ Achievements of sugarcane production in various plans of India are explained in the table 1.

Table 1. Achievements of sugarcane production in various plans

\begin{tabular}{|l|l|l|}
\hline Plans & Sugarcane (in million tonnes) \\
\hline & Target & Actual \\
\hline First Plan & 63 & 60 \\
\hline Second Plan & 78 & 104 \\
\hline Third Plan & 100 & 127 \\
\hline Fourth Plan & 150 & 140 \\
\hline
\end{tabular}

\footnotetext{
$1 \mathrm{c}$

${ }^{2}$ Misra.S.K., Puri.V.K., Indian Economy, Himalaya Publishing House, Chennai 2010, P.537 
T.S. Krishnamoorthy Durgesh Nandhini \& Venkittanaranappa Padmavathy

\begin{tabular}{|l|l|l|}
\hline \hline Fifth Plan & 165 & 165 \\
\hline Sixth Plan & 215 & 170 \\
\hline Seventh Plan & 217 & 170 \\
\hline Eighth Plan & 275 & 277 \\
\hline Ninth Plan & 336 & 300 \\
\hline Tenth Plan & 336 & 345 \\
\hline Eleventh Plan & - & 357.7 \\
\hline
\end{tabular}

Source: Plan documents and Economic surveys

\section{Sugarcane as a commercial crop:}

Sugarcane is a major cash crop in India responsible for the overall socio-economic development of the farming community. Molasses, sugar and khandsari etc, are produced from the juice of sugarcane. Production of the crop is mainly located in the states of Uttar Pradesh, Maharashtra, Tamil Nadu, Karnataka and Gujarat. Sugarcane cultivation needs temperature of 15 degree to 40 degree and rainfall of 100 to 150 centimeters and fertile loamy soil or hard soil. Sugarcane is a long duration crop which produces huge amounts of biomass, requiring large quantities of water, which typically are supplied through 25-30 irrigation cycles per crop season sugarcane is cultivated from Kanyakumari (southern Part) to Punjab (north - west) but it is more cultivated in Uttar Pradesh, except these States, sugarcane is an important crop in Maharashtra, Tamil Nadu, Andhra Pradesh, Karnataka, Punjab, Haryana, and Bihar etc. In India, the sugar industry is the second largest agriculture based industry after textile fibers. It arises over INR 225 billion in taxes for the common wealth and stategovernments. ${ }^{3}$ Chart 3 explains the five year plan periods and achievements of sugarcane production in graphical representation.

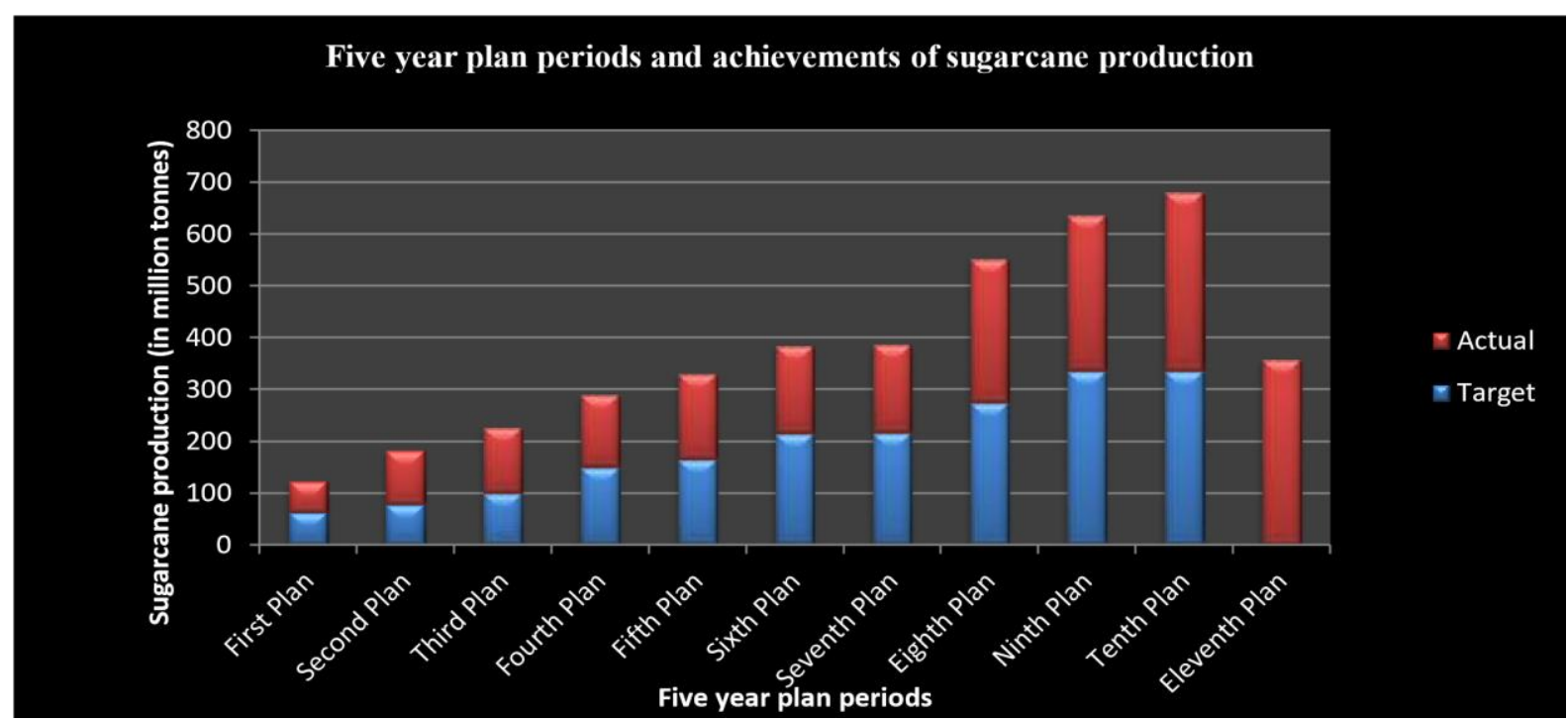

Indian sugarcane production statistics and percentage are described in the chart 4

\begin{tabular}{|ll|}
\hline$\bullet$ & $78 \%$ of sugarcane is used for sugar production \\
\hline$\bullet$ & $15 \%$ of the crop is used for the production of various other sweets (gur) \\
\hline$\bullet$ & $7 \%$ of sugarcane is used for bio - fuel production \\
\hline & There are 468 sugar mills functioning in India \\
\hline
\end{tabular}

\section{MeTHODOLOGY}

This study is based on secondary data. The data on sugarcane production in India was collected from various sources such as http://www.indiastat.com, http://agricrop.nic.in/and other websites, books, journals.

Annual percentage growth rate was used $=(\mathrm{Cm}-\mathrm{Pm} / \mathrm{Pm}) * 100$

Where, $\mathrm{Cm}$ - Sugarcane production in the current year chosen

$\mathrm{Pm}$ - Sugarcane production in the previous year

\footnotetext{
${ }^{3}$ http://www.thecropsite.com/articles/1697/record-india-sugarcane-cum-commercialcash-crop ${ }^{4}$ http://www.statisia.com/topics/1224/sugar/
} 
To find the trend line in production of sugarcane in India the simple linear regression has been applied by using the following formula

$\mathrm{Y}=\mathrm{a}+\mathrm{bXt}$

Where, $\mathrm{Y}$ - Sugarcane production, $\mathrm{a}$ - intercept, $\mathrm{b}$ - slope co-efficient, $\mathrm{Xt}$ - year

\section{RESULTS AND DISCUSSIONS}

A. Nagarajan (2013) was conducted a study on "sustainable farming practices in sugarcane cultivation". The objective was to minimize the cost of production and maximize the productivity without affecting the environment and certain steps need to be wakened for sugarcane cultivation such as land preparation practice, planting sets practice, water management practice, inter cropping management practice, ratoon management practice, harvesting management practice and from these practices they concluded that it was a great help to evaluate the adoption of different sustainable sugarcane farming practices. ${ }^{4}$

Dr.S.D.Sundar singh and R. Veeraputhiranhas had conducted a study on "irrigation management in sugarcane"(2000) and concluded that Tamil Nadu was the leading producer of sugarcane was compared to other states. But, the scarcity of water was a limiting factor. Water was vital in certain stages of growth of sugarcane. Irrigation water was essential yet a constraint in sugarcane production, efficient supply of water, considering the soil, climate, crop, environment conditions was important. The various strategies include selection of varieties, mulching, and gradual widening of furrows, alternate furrow method of irrigation, drip irrigation, and an innovative method called surge irrigation. The authors stressed in the fact that an optimum soil moisture environment was a pre-requisite to reduce the adverse of shoot borer in sugarcane. ${ }^{5}$ In this paper it will analyze the sugarcane production in all states in India and it updates the trend and relevant need for changes that would lead to progress the production of sugarcane in India.

Similarly this study tries to picture the production of sugarcane in India and its impacts in Indian economy. The table 4 indicates the production of sugarcane in India.

Table 2. Production of sugarcane in India

\begin{tabular}{|l|l|l|}
\hline Year & Production ('000 tonne) & Annual percentage growth rate \\
\hline $2000-01$ & 296368 & - \\
\hline $2001-02$ & 297650 & 0.43 \\
\hline $2002-03$ & 287828 & -3.30 \\
\hline $2003-04$ & 234327 & -18.59 \\
\hline $2004-05$ & 237598 & 1.40 \\
\hline $2005-06$ & 281710 & 18.57 \\
\hline $2006-07$ & 356019 & 26.38 \\
\hline $2007-08$ & 348402 & -2.14 \\
\hline $2008-09$ & 285781 & -17.97 \\
\hline $2009-10$ & 293356 & 2.65 \\
\hline $2010-11$ & 343491 & 17.09 \\
\hline $2011-12$ & 362167 & 5.44 \\
\hline
\end{tabular}

Source: www.indiastat.com

Table 2 reveals that there was lot of fluctuations observed in the production of sugarcane in India. Production of sugarcane attained a record level of 356019 thousand tons during 2006-07, after which it declined in the subsequent years. The annual percentage growth rate was found negative for four years $(2002-04,2007-08)$ in the study period. A consecutive increase was found in the annual percentage growth rate from 2004-07 and 2009-12. The highest growth rate was compared to the previous year was witnessed in 2006-07 as 26.4 percent. In 2006-07, the production has increased due

\footnotetext{
${ }^{4}$ Nagarajan,"Sustainable farming practices in sugarcane cultivation", Kisanworld, ajournal of agriculture and Rural Development, Vol 40, Jan 2013, pp. 28 - 31

${ }^{5}$ Sundar singh and Veeraputhiran,"Enhancing sugarcane productivity”, Kisanworld, A journal of Agriculture and Rural Development', June 2000, pp. 18-19.
} 


\section{T.S. Krishnamoorthy Durgesh Nandhini \& Venkittanaranappa Padmavathy}

to the favorable weather condition and again declined in 2008-09. Long hours of sunshine, cool nights with clear skies and the latitudinal position of area were highly favorable for sugar accumulation. ${ }^{6}$

\subsection{State-Wise Production of Sugarcane in India}

The major sugarcane in nine states in India. Sugarcane is important for people and it is related to the culture and tradition of Indian people. This table 3 shows the state-wise production in India.

Table 2. State-wise production of sugarcane in India

State-nise Production of sugarcane in India

\begin{tabular}{|c|c|c|c|c|c|c|c|c|c|c|c|c|c|c|c|c|c|c|}
\hline Year & Andhra pradest 9 & & Assam & $\%$ & Bihar & $\%$ & Gujarat 9 & $\%$ & Haryana & $\%$ & Karnataka & $\%$ & Maharashtra $\%$ & Tamil Nada $\%$ & Tttar Pradesh $\%$ & Others & $\%$ & India \\
\hline $2000-01$ & 176906 & 6.0 & 988 & 0.3 & 3988 & 1.3 & 12695 & 4.3 & 8170 & 28 & 42923 & 14.5 & $\begin{array}{l}49589 \\
\end{array}$ & \begin{tabular}{l|l|}
33188 & 11.2 \\
\end{tabular} & \begin{tabular}{|l|l|}
106068 & 35.8 \\
\end{tabular} & $8 \quad 21069$ & 7.1 & 296368 \\
\hline $2001-02$ & \begin{tabular}{l|l}
18082 & 6 \\
\end{tabular} & 6.1 & 1011 & 0.3 & 5211 & 1.8 & 12465 & 4.2 & 9270 & 3.1 & 33017 & 11.1 & \begin{tabular}{l|l|l|}
45140.2 \\
\end{tabular} & \begin{tabular}{|l|l|}
32620 & 110 \\
\end{tabular} & \begin{tabular}{|l|l|}
117982 & 39.6 \\
\end{tabular} & \begin{tabular}{|l|}
62871 \\
\end{tabular} & 7.7 & 297650 \\
\hline $2002-03$ & 153875 & 5.3 & 916 & 0.3 & 4521 & 1.6 & 14071 & 4.9 & 10650 & 3.7 & 32485 & 11.3 & \begin{tabular}{|l|l|}
42617 & 14.8 \\
\end{tabular} & \begin{tabular}{l|l|}
24165 & 8.4 \\
\end{tabular} & $120948 \quad 42.0$ & 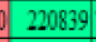 & 76.7 & 287828 \\
\hline $2003-04$ & \begin{tabular}{l|l}
15070 & 6 \\
\end{tabular} & 6.4 & 981 & 0.4 & 4286 & 1.8 & 12669 & 5.4 & 9280 & 4.0 & 16015 & 6.8 & 2566811.0 & \begin{tabular}{l|l|}
17656 & 75 \\
\end{tabular} & 11275448.1 & \begin{tabular}{|l|l|}
19963 \\
\end{tabular} & 8.5 & 234327 \\
\hline $2004-05$ & \begin{tabular}{l|l|l|}
157396 \\
\end{tabular} & 6.6 & 884 & 0.4 & 4112 & 1.7 & 14570 & 6.1 & 8060 & 3.4 & 14276 & 6.0 & \begin{tabular}{l|l|}
20475 & 8.6 \\
\end{tabular} & \begin{tabular}{l|l}
23396 & 9.8 \\
\end{tabular} & 11871650.0 & 7384 & \begin{tabular}{|c|}
473 \\
\end{tabular} & 237598 \\
\hline $2005-06$ & \begin{tabular}{ll|l}
17656 & 6 \\
\end{tabular} & 6.3 & 871 & 0.3 & 4338 & 1.5 & 14580 & 5.2 & 8180 & 29 & 18267 & 6.5 & \begin{tabular}{ll|l}
38853 & 13.8 \\
\end{tabular} & \begin{tabular}{l|l|}
35107 & 12.5 \\
\end{tabular} & \begin{tabular}{l|l|l|}
125470 & 44.5 \\
\end{tabular} & \begin{tabular}{|l|l|}
5 & 18405 \\
\end{tabular} & 6.5 & 281710 \\
\hline $2006-07$ & \begin{tabular}{l|l|}
21692 & 6 \\
\end{tabular} & 6.1 & 1055 & 0.3 & 5956 & 1.7 & 15630 & 4.4 & 9580 & 27 & 28670 & 8.1 & \begin{tabular}{ll|l|l|}
78568 & 22.1 \\
\end{tabular} & 4112411.6 & 13394937.6 & $6 \quad 19812$ & 2.6 & 356019 \\
\hline $2007-08$ & 202965 & 5.8 & 980 & 0.3 & 3855 & 1.1 & 15190 & 4.4 & 8860 & 25 & 26240 & 7.5 & 8843725.4 & $\begin{array}{lll}38071 & 109 \\
\end{array}$ & \begin{tabular}{ll|l}
124665 & 35.8 \\
\end{tabular} & $8 \quad 21830$ & 63 & 348402 \\
\hline $2008-09$ & \begin{tabular}{l|l|l}
15380 & 5 \\
\end{tabular} & 5.4 & 1100 & 0.4 & 4960 & 1.7 & 15510 & 5.4 & 5130 & 1.8 & 23328 & 8.2 & 6064821.2 & \begin{tabular}{ll|l}
32804 & 11.5 \\
\end{tabular} & \begin{tabular}{|l|l|}
109048 & 38.2 \\
\end{tabular} & \begin{tabular}{|l|l|}
2 & 17896 \\
\end{tabular} & 6.3. & 285781 \\
\hline $2009-10$ & 117084 & 4.0 & 1059 & 0.4 & 5032 & 1.7 & 12400 & 4.2 & 5335 & 1.8 & 30443 & 10.4 & \begin{tabular}{ll|l|}
64159 & 21.9 \\
\end{tabular} & \begin{tabular}{l|l}
29746 & 10.1 \\
\end{tabular} & 117140399 & 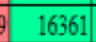 & 5.6 & 293356 \\
\hline 2010-11 & 149644 & 4.4 & 1075 & 0.3 & 12763 & 3.7 & 13760 & 4.0 & 6042 & 1.8 & 39657 & 11.5 & 8189623.8 & \begin{tabular}{ll|l}
34252 & 100 \\
\end{tabular} & \begin{tabular}{l|l|l}
120545 & 35.1 \\
\end{tabular} & \begin{tabular}{|l|l|}
1 & 18566 \\
\end{tabular} & 5.4 & 343491 \\
\hline $2011-12$ & $\begin{array}{l}16686 \\
\end{array}$ & 4.6 & 993 & 0.3 & 11289 & 3.1 & 12750 & 3.5 & 6959 & 19 & 38808 & 10.7 & $86733 \mid 23.9$ & \begin{tabular}{l|l|}
38576 & 10.7 \\
\end{tabular} & \begin{tabular}{l|l|}
128819 & 35.6 \\
\end{tabular} & 620583.5 & 5.7 & 362167 \\
\hline
\end{tabular}

Source: www.indiastatcom

Percentage tool was used to analyze the state-wise production of sugarcane in India.

Percentage $=($ Production of State $/$ Total Production of India $) * 100$

Table 2 depicts the state-wise production of sugarcane in India. Uttar Pradesh and Maharashtra stood the first and second places continuously throughout the study period. Assam has the lowest production of sugarcane in India. The States such as Arunachal Pradesh,

Andaman and Nicobar Islands, Chhattisgarh, Goa, Himachal Pradesh, Jammu and Kashmir, Jharkhand, Kerala, Madhya Pradesh, Manipur, Meghalaya, Mizoram, Nagaland, Odisha, Pondicherry, Punjab, Rajasthan, Tripura, Uttarkhand and West Bengal are in the others category with minimal production. The Percentage share of Uttar Pradesh was 35.8 per cent in 2000-01, it was the highest in 2004-05 (50 percent) after which it was started declining, though it was still the topper state, the production was only 35.6 percent in 2011-12. The share of Bihar varied from 1 to 3 percentages. The percentage share of Assam was less than 0.5 in all the years.

Assam was the least producer of sugarcane in India. The reasons for the low production and productivity of Assam was land fragmentation, lack of modern technology, or continued reliance on rain for irrigation, there are several other problems that hinder the development of agricultural sector in Assam. In 2001-02, a minimal increase in area was observed. After which was a continuous fall in acreage till 2005-06. During this period, though there was a continuous fall in area but the productivity showed a hike. This is due to technological advancement like improvement in mechanization. In 2006-07 all the three components were found at its highest. In years of increase in area, an increase in productivity is evident except for the year 2010-11, while in spite of increase in area, the productivity of sugarcane has declined.

The production of sugarcane in Andhra Pradesh in 2003-04 has declined to 15070 thousand tonnes from 18082 thousand tonnes in 2001-02. This was because of unfavorable weather condition. The production has showed a negative growth compared to the previous year. After 2004-05, there was an increase in production up to 2006-07. In the production of sugarcane, Andhra Pradesh stood the sixth rank among the nine states in India.

The north of Bihar was agro-climatically were very suitable for producing good quality with monsoon inputs as compared to other states. But the production of sugarcane in Bihar was very low and this state was ranked the second least producer of sugarcane after Assam. A large number of existing sugar mills run under the State, Bihar sugar corporation had to be closed due to old and obsolete

\footnotetext{
${ }^{6}$ Nagarajan,"Sustainable farming practices in sugarcane cultivation", Kisan world, A journal of agriculture and Rural Development, Vol 40, Jan 2013, pp. 28 - 31
} 
equipment skills, as modernization of the existing plant and equipment and retraining of personnel had not been undertaken by these sugar mills. These are the main reasons for low production and productivity of sugarcane.

The highest production of sugarcane in Gujarat was at 2006-07 about 15630 thousand tonnes. Gujarat stood fifth place in yield of sugarcane and in production it took the seventh place. There was low production in 2001-02 was negative at -1.2 percent. In 2002-03 the production has increased to 14071 thousand tonnes from 12465 thousand tonne in 2001-02. In 2003-04, the area and production was negative but the productivity was high because of increase in electricity supply to agriculture for promoting irrigation and thus the output rose. In 2004-05 also, there was an increase in production and it continued till 2011-12, except one year 2009-10 during which an increase in productivity was witnessed.

Haryana ranked the sixth in production and productivity of sugarcane in India. In 2002-03, the productivity was very low. In 2007 to 2009 , the annual production and productivity was very low. In 2010-11, there was a positive annual growth in production.

The production of sugarcane in Karnataka stood at third position. There was a negative annual percentage growth rate of area and production. But in productivity, there was a positive growth rate in 2004-05. Then there were some fluctuations in productivity. The production of Maharashtra is the second among the nine sugarcane producing states. In 2010-11 there was an increase in area and production, but the annual change in productivity was zero compared to the previous year. The production of sugarcane in Tamil Nadu has touched the peak at 41124 thousand tonnes in 2006-07. Tamil Nadu stood at fourth place in production of sugarcane and first place in yield. In 2007 to 2010, there was a decline in annual area, production and productivity was low because of low quality of crops, outmoded agricultural techniques and population pressure. In 2010-11, there was an increase in area, production and productivity.

The production of sugarcane in Uttar Pradesh was the first among all the sugarcane producing states in India. In 2001-02, there was an increase in area, production and productivity. In 200709 all the three elements had negative annual percentage growth rate, which was found to be positive in 201112.

\section{Conclusion}

The analysis of the secondary data on production of sugarcane in India has revealed that there were variations in production. It was evident from the trend equations that there were fluctuations in the production of sugarcane in India, no uniform pattern of growth was observed. It is hereby to conclude that the major reason for low production and low productivity is the unpredictable monsoon conditions. Thus initiatives on proper irrigation management would enable the scope and increase the production of sugarcane in India.

\section{REFERENCES}

[1] Misra.S.K., Puri.V.K., Indian Economy, Himalaya Publishing House, Chennai 2010, P.537

[2] Nagarajan,"Sustainable farming practices in sugarcane cultivation", Kisan world, A journal of agriculture and Rural Development, Vol 40, Jan 2013, pp. 28 - 31

[3] Sundar singh and Veeraputhiran,"Enhancing sugarcane productivity", Kisanworld, A journal of Agriculture and Rural Development', June 2000, pp. 18-19.

[4] http://www.thecropsite.com/articles/1697/record-india-sugarcane-cum-commercial-cashcrop

[5] http://www.statisia.com/topics/1224/sugar/

[6] http://www.statisia.com/topics/1224/sugar/

[7] Venkatraman, "Importance of Ratoon crop", Kisan world, A Journal of agriculture and Rural development, vol 36, April 2009

[8] http://www.indiatat.com/

[9] http://www.sugarcanecrops.com/introduction

[10] Murugesan and Natarajan, "Enhancing sugarcane productivity", Kisan world, A journal of Agriculture and rural Development, Vol 40, June 2000 